Pancreatic Cysts, with some Remarks upon Treatment, Edinburgh Medical Journal, vol. xli, 1895-6, p. 423 . McPhedran, Dr. A.: Remarks on Cases of Pancreatitis followed by Cyst of the Pancreas, BRITISH MEDICAL JouRNAL vol. i, 1897, p. 1400. Ormsby: Removal of a Large Omental Tumour by Abdominal Section, British Medical Journal, vol. i, 1883, p. 578. Park, Roswell : Treatise on Surgery (article on Pancreatic Tumours by Maurice Richardson and Farrar Cobb), 1896. Poncet et (Sibert: Gros Kyst Glandulaire de la Queue du Pancreas, Gazette des IIôpitaux, 1896, p. 347. Railton, Dr. T. C.: A Case of Pancreatic Cyst in an Infant, BRitis MEDICAL JoURNal, vol. ii, 1896, p, 1318. Von Recklinghausen: Di Adenomyome und Cystadenome der Uterus und Tubenwandung, ihre Abkunft von Restcn des Wolffschen Körpers, 1896. Reddingius: Bijdrage tot de Casuistick der Pancreas-aandoeningen. Nederlandsch Tijdschrift voo Geneeskunde, No. ro, 1892. Savill, T., M.D.: Pancreatıc Cyst; Retroper toneal Rupture: Peritonitis: Death, Lancti, vol. ii. 18gr.p 666 . Sendler: Zur Pathologie und Chirurgie des Pancreas, Deutsche Zeitschrift fïr Chirur gie, xliv., 1896, p. 329. Shattock and Bernard Pitts : Calculi of Calcium Oxa]ate from a Cyst of the Pancreas, Journal of Pathology and Bacteriology vol. iv, p. 219, and Trans. Path. Soc., vol. xlvii, 1896, p. ror. Treves: System of Surgery, vol. ii, p. 587, and Lancet, vol. ii, 1890, p. 655. De Wildt : Een Geval van Pancreascyste, Weekblad van het Nederlandsch Tijdschrift voor Geneeskunde, No. 5, 1892. Zweifel : Extirpation einer Pankreascyste, Centralbl.f. Gynäkol., 1894, No. 27.

\section{ON SOME PECULIAR PIGMENTED CELLS FOUND IN TWO MOSQUITOS FED ON MALARIAL BLOOD.}

By SuRgeon-Major RONALD ROSS, I.M.S., (With Note by Surgeon-Major SMYTH, M.D., I.M.S.)

For the last two years I have been endeavouring to cultivate the parasite of malaria in the mosquito. The method adopted has been to feed mosquitos, bred in bottles from the larva, on patients having crescents in the blood, and then to examine their tissues for parasites similar to the hæmamœba in man. The study is a difficult one, as there is no a priori indication of what the derived parasite will be like precisely, nor in what particular species of insect the experiment will be successful, while the investigation requires a thorough knowledge of the minute anatomy of the mosquito. Hitherto the species employed have been mostly brindled and grey varieties of the insect; but though I have been able to find no fewer than six new parasites of the mosquito, namely, a nematode, a fungus, a gregarine, a sarcosporidium (?), a coccidium (?), and certain swarm spores in the stomach, besides one or two doubtfully parasitic forms, I have not yet succeeded in tracing any parasite to the ingestion of malarial blood, nor in observing special protozoa in the evacuations due to such ingestion. Lately, however, on abandoning the brindled and grey mosquitos and commencing similar work on a new brown species, of which I have as yet obtained very few individuals, I succeeded in finding in two of them certain remarkable and suspicious cells containing pigment identical in appearance to that of the parasite of malaria. As these cells appear to me to be very worthy of attention, while the peculiar species of mosquito seems most unfortunately to be so rare in this place that it may be a long time before I can procure any more for further study, I think it would be advisable to place on record a brief description both of the cells and of the mosquitos.

The latter are a large brown species, biting well in the daytime, and incidentally found to be capable of harbouring the filaria sanguinis hominis. The back of the thorax and abdomen is a light fawn colour; the lower surface of the same, and the terminal segment of the body a dark chocolate brown. The wings are light brown to white, and have four dark spots on the anterior nervure. The haustellum and tarsi are brindled dark and light brown. The eggs-at least, when not fully developed-are shaped curiously like ancient boats with raised stern and prow, and have lines radiating from the concave border like banks of oars-so far as 1 have seen, a unique shape for mosquito's eggs. The species appears to belong to a family distinct from the ordinary brindled and grey insects; but there is an allied species here, only more slender, whiter, and much less voracious. My observations on the characteristics of these mosquitos were not very careful, as when I first obtained them I did not anticipate any difficulty in procuring more.

On August 16 th eight of them were fed on a patient whose blood contained fair to few crescents (and also filariæ). Unfortunately four were killed at once for the study of flagel- late bodies (flagellulæ cysts). Of the remainder two were examined on the 18 th and 20 th respectively, without anything being noted. The seventh insect was also killed on the $20 t h$, four days after having been fed. On turning to the stomach with an oil-immersion lens I was struck at once by the appearance of some cells which seemed to be slightly more substantial than the cells of the mosquito's stomach usually are. There were a dozen of them lying among (or within ?) the cells of the upper half of the organ, and, though somewhat more solid than these, still very delicate and colourless. They were round or oval, 12 $\mu$ to $16 \mu$ in diameter when not cornpressed (that is, considerably largen than the largest hæmamœba in man); the outline sharp but very fine; the contents full of stationary vacuoles; and no sign of apparent nucleus, contractile vesicle or amœboid or intracellular movement. So far it would have been impossible for any but a person very familiar with the insect's anatomy to have distinguished them from the neighbouring cells; but what now arrested attention was the fact that each of these bodies contained a few granules of black pigment absolutely identical in appearance with the wellknown and characteristic pigment of the parasite of malaria (large quartans and crescent-derived spheres).

The granules were more scanty in comparison to the size of the cell than in the hæmamœba, and numbered from ro to 20 in each. They were not dispersed throughout the cells, but were collected in groups, or arranged in lines transversely or peripherally, or in a small circle round the centre (just as in some forms of the hæmamœba). They were black or dark brown, and not refractive on change of focus. In some cases they showed rapid oscillation within a small range, but did not change their position. Owing to their blackness, so different from the bluish, yellow, and green granules and iebris found in and about the neighbouring cells, they arrested the eye at once; and it must clearly be understood that I have not confounded them with normal objects. In short (except perhaps that rods were shorter or absent) these granules of pigment were indistinguishable from those of the hæmamœba.

The eighth and last mosquito was killed next day, five days after having been fed. The stomach contained precisely the same cells, 21 in all, again toward the osophageal end of the organ. In this case, however, they were distinctly larger and more substantial than in the seventh mosquito, and had a decidedly thicker outline. The size (along the major axis) appeared now sometimes to reach nearly $20 \mu$, on a rough computation made without a micrometer. There thus appeared to be a marked increase in bulk and definition between these cells of the fourth and fifth days, suggesting that they had grown in the interval.

Both specimens were irrigated with 40 per cent. formalin, and sealed. The result of the formalin was, as anticipated, that the bodies became slightly more visible than before, as compared with the stomach cells.

In spite of all attempts, I have not yet succeeded in obtaining any more of the species of mosquito referred to. Thinking, however, that I may have overlooked these delicate cells in former dissections, I have again examined a large number of brindled and grey mosquitos, fed on malarial blood. Their stomachs certainly contained no such cells. Next I caught by hand a number of the more slender and white, but allied, species already referred to (I have failed in finding their grubs also), and examined them. Some had not been fed at all, and others had fed themselves on (presumably) healthy blood, two, three, or four days previously. The results were again negative. I may add that I have not yet succeeded in getting this species fed on malarial blood.

To sum up : The cells appear to be very exceptional; they have as yet been found only in a single species of mosquito fed on malarial blood; they seem to grow between the fourth and fifth day; and they contain the characteristic pigment of the parasite of malaria. It would, of course, be absurd to attempt final conclusions as yet; but I think we may venture to draw some cautious inferences on these observations. First, as to the nature of the cells. Judging from the facts that the elementary cells of allied species of mosquitos are always alike, or very similar, and that I have never observed such bodies in previous or subsequent dissections of mosquitos (I suppose I must have examined quite a thousand 
more or less carefully by this time), we may reasonably conjecture that these are no normal physiological cells -in other words, that they are parasites; and this view is fortified by the comparative substantiality of the bodies, by the appearance of growth between the fourth and fifth days, and, most notably, by their possession of pigment, a substance in my experience certainly quite foreign to the physiological cells of the mosquito. Secondly, as to the connection of these presumable parasites with the parasite of malaria: they have been found in two consecutive insects fed on malarial blood (owing to their delicacy, and to my attention not having yet been attracted by them. I may have overlooked them in the fifth and sixth mosquitos), a fact which may encourage us to believe that they may exist in a large percentage of similar insects similarly fed; and as they have not been found in an allied species fed on presumably healthy blood, we may hazard a conjecture that their presence in the original species was due to the ingestion of malarial blood. These considerations, taken together with the remarkable fact that the cells contain pigment just like that of the hæmamœba (a characteristic product which is, I believe, unknown in any other protozea except some allied hæmatozoa) seem to open the question of their being indeed the form of the hæmamœba we are in search of-namely, the alternative form in the mosquito of the parasite of malaria in man.

On the other hand, the parasitic nature of the cells cannot finally be accepted until certain facts as to structure, sporulation, and so on, have been demonstrated. Even if this be done, it remains to be seen whether the bodies are not parasites common in the particular species of mosquito referred to, and quite independent of the ingestion of malarial blood and of the hæmamcba in man. I must, however, confess to feeling personally that the presence of pigment, so distinctive of the hæmamceba, renders this last supposition rather anlikely.

In conclusion I may note that the pigment in the cells may be derived from the hæmoglobin in the insect's stomach, in the walls of which the cells are situated. With reference to their being found as yet only in one species of mosquito, it may be remembered that Manson originally conjectured that each species of hæmamœba might require a special species of mosquito for development extraneous to man, just as filaria embryos do.

The two specimens containing the cells described above will be forwarded to Dr. Manson. Former specimens of microscopic objects sent to England by me have perished en route, and lest these should experience a similar fate I have thought it well to have an independent note on the subject on record. With this object $I$ append a description of the eells furnished by Surgeon-Major Smyth, who has very kindly examined the specimens. I should add that his measurements, made with a micrometer, are more exact than mine.

Note ON Two MICROScopic PReparations OF THE MOS-

Quitos By Surgeon-Major John Smyth, M.D., I.M.S.

Preparation I. - A mosquito dissected and mounted seventeen days ago in 40 per cent. formalin. The mosquito had been fed five days before dissection on blood containing crescents. (These particulars were supplied by SurgeonMajor Ross.) I used for the examination a Leitz $\frac{1}{12} 0.9$, and Baker's No. 4 eyepiece.

Description.-Fragments of air tubes and plumes are conspicuous in the specimen. Here and there are large oval or nearly circular cells containing pigment. There are about twenty of these in the preparation. Taking a field containing about three of these bodies the following would be a description of it: (I) An indistinct groundwork of the altered stomach cells of the insect. (2) A few coils of air tube. (3) The large pigmented cells referred to above. Taking their major diameters, their size ranges between $0.0187 \mathrm{~mm}$. and $0.0112 \mathrm{~mm}$. They are colourless, faintly granular, present one or two "vacuoles," and have a sharply defined border (a very delicate cell wall or capsule ?). Black pigment granules are found in them, variously arranged, but mostly forming clusters. The number of granules varies from ten to eighteen. In some of them the clustering is nearly or quite central, in others it is marginal. When the latter is the case two or three granules may be seen isolated from the main cluster and arranged in a row along the periphery of the cell. These granules are identical in general appearance with those found in quartan fever; and in Allbutt's System of Medicine (1897) the diagrams of the quartan parasite give a very good genera idea of the appearances in the specimen I have attempted to describe, the only difference being that the former seem to contain a larger number of granules.

Preparation II.-This is a specimen of a mosquito dissected on the fourth day after feeding on blood containing crescents, and prepared on the same date as Preparation I The only difference observable between this preparation and the other is that the pigmented cells are on the whole slightly smaller, ranging between $0.0175 \mathrm{~mm}$. and $0.0075 \mathrm{~mm}$., and are more hyaline and altogether more delicate in structure.

[Surgeon-Major Ronald Ross has been good enough to forward to us the preparations he describes. We have submitted them to Dr. Thin, Mr. Bland Sutton, and Dr. Patrick Manson, who report as follows. Dr. Manson writes: "I have examined Surgeon-Major Ross's slides with great interest, and find that his description of the pigmented cells he refers to is accurate. There can be no question that.these cells contain a pigment optically indistinguishable from the pigment which is so characteristic a feature in the malaria parasite. The cells are evidently in the wall of the insect's stomach, and are quite different in appearance from any other structure in the preparations. They stand out with remarkable distinctness, the outline of the cell wall, if such it be, being sharply defined, the entire body reminding one of a coccidium-invaded epithelial cell. Until these cells have been stained and their exact structure more carefully studied, it is impossible to say if they contain parasites. Considering the peculiar grouping of the pigment in many instances, a grouping that forcibly recalls what one sees in the living malaria parasite, and the distinctness and regularity of the outlines of the bodies, I am inclined to think that Ross may have found the extracorporeal phase of malaria. If this be the case, then he has made a discovery of the first importance. It is just possible, however, that these cells may be something quite other than this. Possibly, if they do contain a parasite, it may be that this parasite is not the malaria parasite; possibly these pigmented cells are normal to the species of mosquito he is working with; possibly the pigment, though malarial, does not represent a living parasite, for we can conceive that a pigment having been set free in the stomach of the malaria-fed mosquito may be taken up by the cells in the insect's stomach. More work is required before the matter can be finally settled. I have been so impressed by the possibilities of Ross's discovery that I had the accompanying drawings made from his preparations."

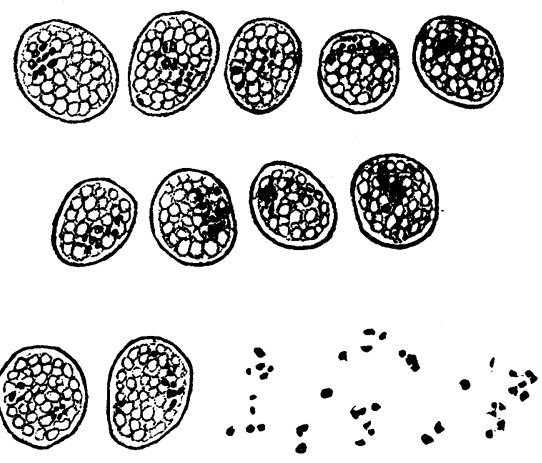

Mr. Bland Sutton writes: "I have examined Surgeon-Major Ross's specimens, and had an opportunity of discussing the matter with Dr. Manson, and thoroughly endorse his opinion. We must wait until experiments demonstrate the subsequent fate of the intracellular particles before coming to a positive decision. It is a peculiarly interesting and important research and one which the skill and enthusiasm of SurgeonMajor Ross will doubtless bring to a satisfactory conclusion." Dr. Thin writes: "Dr. Manson has been good enough to show me Surgeon-Major Ross's two specimens. I beliere that the objects referred to are epithelial cells, and that the 
black granules which they contain are pigment derived from the parnsite of malaria. (1) The pigment: The pigment is found in the form of very minute needles, and in small spheres of varying sizes, but none of them large. This coincides exactly with the forms of pigment observed in the human subject when patients have died of malaria. In the cells of the spleen of patients who have died at Sierra Leone, I found in some of the cells minute needle-shaped pigment in others both needle-shaped and minute spheres in the same cell, in others only spheres of pigment. By the time the cells have reached the liver the pigment in my cases had all become spherical. Even if I had not known that I was looking at a mosquito's stomach, and that that mosquito had been fed on blood containing crescents, the appearances would at once have suggested to me that I was looking at malarial pigment. The position of the pigment in the cells is accurately described by Surgeon-Major Ross. In some of the cells it is irregularly distributed in the periphery, and in others in a small circle towards the centre. There are also small pigment spheres scattered throughout the preparations, without any apparent connection with cells, and the pigment spheres when it was apparently extracellular, were somewhat larger than those which were within cells. (2) The cells: The cells have the outlines of epithelial cells, and they stand out clearly against the other structures in the preparations. I believe they are the ordinary epithelial cells of the stomach of the mosquito which have undergone change, and for the following reason. I saw the preparations twice. The first time I saw them these cell-like bodies stood out very clearly in a field in which the other elements were very transparent and indistinct. The whole field was covered with minute spherical refractive appearances which seemed to be both outside and inside the cells. Before I examined the preparations the second time some change had taken place (probably by the introduction of cedar oil under the edge) which caused all the tissues to refract the light more strongly. The result was to render them much more favourable for observation The numerous minute spherical particles no longer arrested the attention. The bodies in question were, as before, more distinct than anything else in the field, but in addition a number of other cells of the same size and general shape had come into view, presenting the ordinary appearances of epithelial cells, and in many of them the nucleus was distinct. On closer observation it was seen that the epithelial cells were arranged in rows in contact with each other, and that in some of them minute needles or spheres of pigment were present, and that the cells in which pigment was present stood out more distinct!y than those which did not contain pigment. No doubt was, therefore, left in my mind that the bodies in question were the ordinary epithelial cells of the mosquito's stomach containing malarial pigment, and it became evident to me that when one of the epithelial cells of the stomach is infected with malarial pigment it undergoes changes-I have no doubt of a destructive or post-mortem character-which alter the refractive characte of the cell, and make it stand clearly out on a transparent background. The small circles of pigment which are to be seen in some of these bodies are so arranged as to render it almost certain that they are arranged round the nucleus of the epithelial cell. I found in the Sierra Leone cases, in the large white cells of the spleen that were not much infected by pigment, that the pigment was first found in the outer part as fine needles, and afterwards was grouped in sphere round the nucleus. How can we account for the infected cel!s standing out so much more clearly than the unaffected cells? I consider this to be analogous to what takes place in the endothelium of the blood vessels in the capillaries of the brain, spleen, and liver in the Sierra Leone cases. The endothelial cells of the capillaries which contain pigment-and many of them do contain pigment-swell and become altered in their substance, shown by their taking up an eosin or cochineal stain when the healthy cells that do not contain pigment do not stain. In the human subject these infected endothelial cells are doomed to destruction. All this was described in the paper which I read at the Royal Medical and Chirurgical Society on October 26th, and illustrated by microscopical preparatinns. Reasoning from analogy, nfer that the epithelial cells in the mosquito's stomach that absorb . pigment are injured by the pigment, are altered by it, and would eventually be killed by it, and that the injured or dead cell poseesses different refractive qualities from a living and uninjured cell, and stands out clearly in an otherwise almost transparent field. It is quite natural to expect that if a mosquito is fed on blood containing crescents, the pigment of these crescents should be found, after the crescents have been destroyed, in or about the stomach of the insect, and as animal cells possess the property of taking up very minute granules (the liver cells as well as the capillary endothelium take up pigment), it is reasonable to infer that they might be found in the cells of the stomach of the mosquito. What is to me extraordinary about the matter, and requires further explanation, is why this appearance is found only in one species of mosquito. I see no trace of the parasite of malaria itself in these preparations, but, as they are unstained, it does not necessarily follow that it is not there. It will be evident, from what $I$ have remarked, that I consider that these appearances do not represent parasites, and that the extra-corporeal stage of the parasite of malaria, which Koch and Pfeiffer were, I believe, the first to suggest might be found in the mosquito, has not yet been observed, for, so far, all the changes in the form of the crescent, and in the throwing out of flagella, which take place in the mosquito's stomach, can be produced at will (as has been shown by my friend Dr. Marshall, and afterwards verified by Dr. Manson), by the simple addition of distilled water. Although I have not been able to satisfy myself that these preparations show any development of the parasite of malaria in the mosquito's stomach, I hope it will not be considered that I undervalue the great importance of Surgeon-Major Ross's investigations. His published papers, and not the least the one to which this note is appended, show that he is a patient, skilful, and indefatigable observer. He has already added considerably to our knowledge of the mosquito and its parasites, and after what has been ascertained of the association of the mosquito with the filaria sanguinis hominis (in connection with which Dr. Manson's name is so distinguished), no one can believe that any information regarding the parasites of the mosquito may not turn out to be of great practical value, as it certainly is of considerable scientific interest. It is therefore, I consider, very important that Surgeon-Major Ross, with his exceptional capacity and opportunities, should continue his investigations not only regarding the mosquito in connection with the parasite of malaria, but also by working in any other lines which his observations point out to him as possibly leading to a solution of the unsolved riddle of the existence of the parasite outside the human body, for outside the human body we know it does and must exist. It is a subject of congratulation to everyone interested in the welfare of India, and indeed in that of the whole tropical world, that men like Surgeon-Major Ross should be found willing to devote themselves to this difficult and fatiguing work. Only men endowed with unusual enthusiasm could be found to devote themselves as he has done to such a task. In the interests of science it is therefore most desirable that support, assistance if required, and every facility should be given to him to enable him to continue his researches."

A LIMITED outbreak of diphtheria occurred recently in Leeds, which at first seemed to be associated with the milk supply. Further inquiry, however, proved that the patients had only been getting milk since their illness had commenced. The infection was probably spread by school influences.

ABERDFEn Royal INFIRMary.-In the old Aberdeen Royal Infirmary two of the wards were named after the Queen and Prince Albert respectively, and by permission of the Queen two of the wards in the new medical pavilion will be similarly designated. Wards have also been named after Princess Beatrice and Princess Louise.

The Liverpoor Mrdical Institution.-Under the will of the late James Muter Turnbull, M.D., F.R.C.P., whose death was announced in the British Medical JournaL some weeks ago, the Liverpool Medical Institution receives a legacy of $65^{\circ}$ free of duty. Dr. Turnbull was President of the Institution for the years $1876-77$. 